\title{
Upper mantle structure beneath the Society hotspot and surrounding region using broadband data from ocean floor and islands
}

\author{
Takehi Isse ${ }^{1 *}$, Hiroko Sugioka ${ }^{2}$, Aki Ito $^{3}$, Hajime Shiobara ${ }^{1}$, Dominique Reymond ${ }^{4}$ and Daisuke Suetsugu ${ }^{3}$
}

\begin{abstract}
We determined the three-dimensional shear wave velocity structure beneath the South Pacific superswell down to a depth of $200 \mathrm{~km}$ by analyzing fundamental Rayleigh wave records from permanent and temporary land-based and seafloor seismometers in the Pacific Ocean. Data from the Tomographic Investigation by seafloor ARray Experiment for the Society hotspot (TIARES) project yield excellent spatial resolution of velocity anomalies in the central part of the superswell, near the Society hotspot. Localized slow anomalies are found near hotspots in the upper mantle, but the vertical profiles of the anomalies vary from location to location: Slow anomalies near the Samoa, Macdonald, Pitcairn, and Society hotspots extend to at least $200 \mathrm{~km}$ depth, while a slow anomaly near the Marquesas hotspot extends only to $\sim 150 \mathrm{~km}$ depth. Owing to the recently deployed seafloor array, horizontal resolutions of slow anomalies near the Society hotspot are substantially improved: The slow anomalies are about $300 \mathrm{~km}$ in lateral extent and have velocity anomalies as low as $-6 \%$. The lithosphere thickness is estimated to be $\sim 70 \mathrm{~km}$ in the vicinity of all hotspots, which may indicate thermal erosion by mantle plumes.
\end{abstract}

Keywords: Society hotspot, South Pacific superswell, Surface wave tomography, Ocean-bottom seismometer

\section{Background}

The French Polynesian region is characterized by largescale positive topographic anomalies that reach $700 \mathrm{~m}$ (Adam and Bonneville 2005), the so-called South Pacific superswell (McNutt 1998), many hotspot chains (e.g., Society, Cook-Austral, Marquesas, and Pitcairn) and large-scale slow seismic velocity anomalies in the lower mantle. Locations of hotspots and the superswell are shown in Fig. 1. Although this area has an anomalous structure, high-resolution tomographic models have yet to be developed, due to the sparse coverage of seismic stations in the South Pacific. To improve the horizontal and vertical resolutions of velocity structure, temporary observations have been conducted.

A French Polynesian Lithosphere and Upper Mantle Experiment (PLUME) project team conducted a

\footnotetext{
*Correspondence: tisse@eri.u-tokyo.ac.jp

'Earthquake Research Institute, The University of Tokyo, 1-1-1 Yayoi,

Bunkyo-ku, Tokyo 113-0032, Japan

Full list of author information is available at the end of the article
}

temporary broadband seismic experiment on oceanic islands in the French Polynesian region from 2001 to 2005 (Barruol et al. 2002). Using a surface wave tomography method, Maggi et al. (2006) found slow anomalies to $400 \mathrm{~km}$ depths at the Macdonald and Society hotspots, with a lateral resolution of $\sim 800 \mathrm{~km}$.

We conducted a temporary seafloor seismic experiment from 2003 to 2005 in the French Polynesian region (Suetsugu et al. 2005) by using broadband ocean-bottom seismometers (BBOBSs), with a flat velocity response in period from 0.02 to $360 \mathrm{~s}$ and a 24-bit data acquisition system. Isse et al. (2006) obtained a shear wave velocity model for the upper mantle (to a depth of $200 \mathrm{~km}$ ) with a $500-\mathrm{km}$ horizontal resolution, by analyzing Rayleigh wave data recorded on oceanic islands and by these BBOBS stations; they found varying slow velocity anomalies associated with each hotspot. Suetsugu et al. (2009) used BBOBS and PLUME data to obtain an improved seismic image beneath the superswell from the lower mantle to the upper mantle. Their work, which combined surface wave tomography, receiver function analysis, and

\section{贷 Springer}

(c) 2016 Isse et al. This article is distributed under the terms of the Creative Commons Attribution 4.0 International License (http:// creativecommons.org/licenses/by/4.0/), which permits unrestricted use, distribution, and reproduction in any medium, provided you give appropriate credit to the original author(s) and the source, provide a link to the Creative Commons license, and indicate if changes were made. 


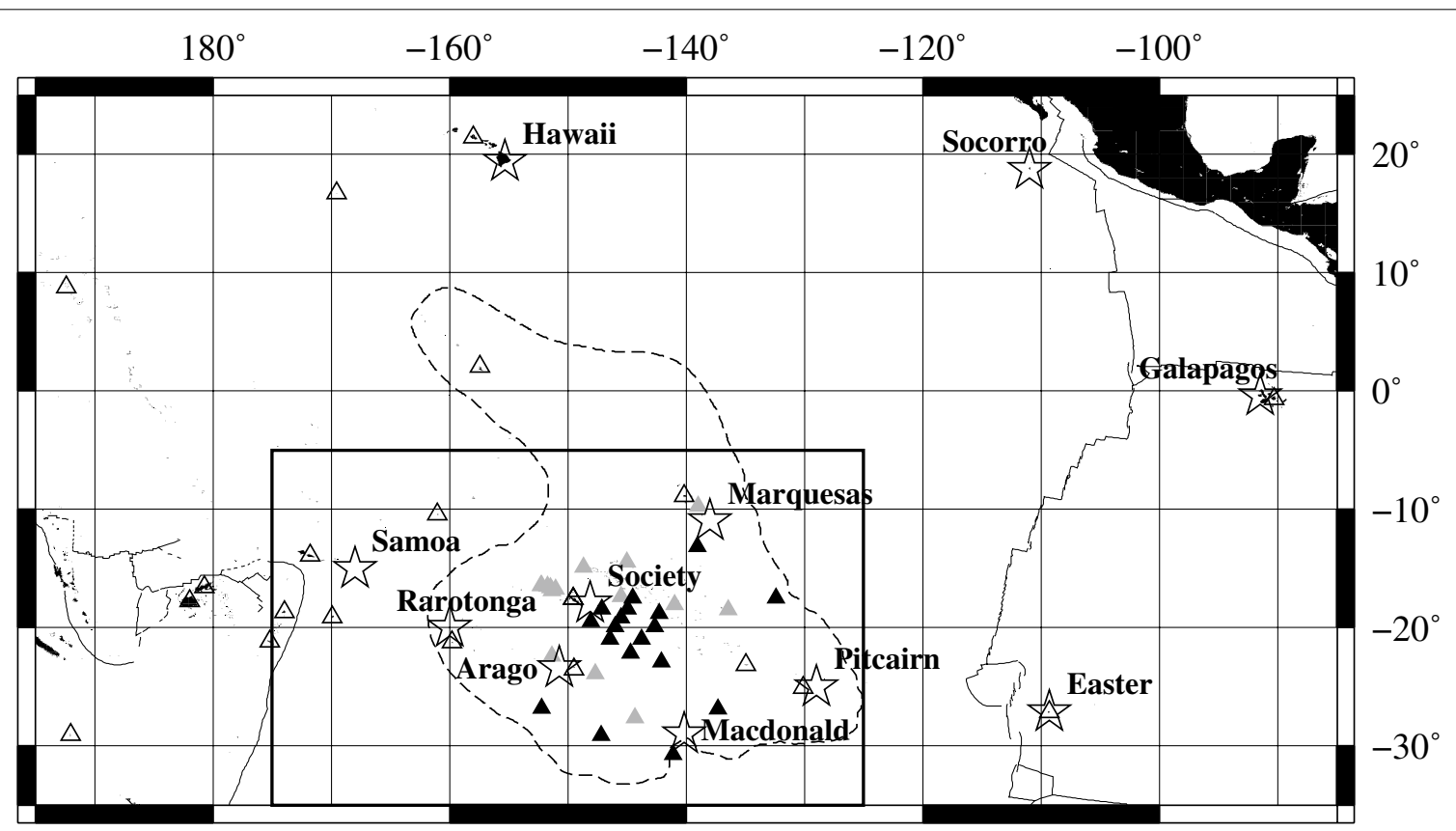

Fig. 1 Map of seismic stations used in the present study. Hotspots and superswell are also shown. Open triangles show permanent land stations by IRIS, Geoscope, SPANET, CEA, and Geoscience Australia. Gray solid triangles show temporary land stations from the GEOFON and PLUME projects, Black solid triangles indicate temporary seafloor broadband stations. Open stars show hotspots. Broken line indicates the superswell region defined by anomalous seafloor uplift greater than $\sim 300 \mathrm{~m}$. Solid lines show plate boundaries. Solid rectangle outlines the studied region

body wave travel time tomography, suggests that largescale slow velocity anomalies exist from the bottom of the mantle to $1000 \mathrm{~km}$ depth, while depth range of narrow slow anomalies in the upper mantle varies for narrow plumes associated with individual hotspots in the upper mantle. They further suggested that the Society and Macdonald hotspots are likely to be deep-rooted (i.e., extending down to the top of the large-scale slow anomalies in the lower mantle), while other hotspots may have shallower origins. The lateral resolution of upper mantle structure from the surface wave analysis was about $500 \mathrm{~km}$ in their model.

Temporary land and seafloor array deployments have improved the lateral resolution of the superswell region, though these are not yet sufficient to reveal detailed manthe structure beneath individual hotspots, such as the relationship between the Society hotspot and slow velocity anomalies nearby. The Tomographic Investigation by seafloor ARray Experiment for the Society hotspot (TIARES) project, conducted from 2009 to 2010, focused on the Society hotspot to investigate the details of the narrow plumes beneath the hotspot from the lower mantle to the surface. The TIARES network consisted of nine BBOBSs paired with ocean-bottom electromagnetometers (OBEMs) (Suetsugu et al. 2012). In the present study, we resolve three-dimensional shear wave velocity structure of the upper mantle beneath the Society hotspot region and surroundings with a higher resolution than that of previous studies, using surface wave tomography that incorporates the TIARES data.

\section{Data}

We analyzed seismograms from temporary and permanent broadband stations installed on islands and the seafloor of the Central and South Pacific. The temporary stations include seven BBOBS stations deployed from 2003 to 2004, two BBOBS stations from 2004 to 2005 (Suetsugu et al. 2005), nine BBOBS stations from 2009 to 2010 by the TIARES project (Suetsugu et al. 2012), 11 island stations from 2001 to 2005 by PLUME project (Barruol et al. 2002), four island stations from 2005 to 2006 by GEOFON, and five island stations by SPANET (Ishida et al. 1999). The permanent stations include two stations operated by Geoscope, three operated by Commissariat à l'Energie Atomique (CEA), ten by GSN, and two by Geoscience Australia. Station locations are shown in Fig. 1. We selected events with $M_{\mathrm{w}}$ or $M_{\mathrm{b}} \geq 5.5$ and epicenters located in and around the Pacific Ocean, occurring between January 1995 and June 2010. In BBOBS observations, a few seconds of absolute time shift are possible during a 1-year seafloor experiment even though the recorder has a very precise clock (Isse et al. 2014); BBOBS observation between 2003 and 2004 had time shifts of $\sim 10-40 \mathrm{~s}$ because relatively old recorders 
were used. We calibrated BBOBS raw data using a linear interpolation method based on the time difference between each recorder's clock and a GPS clock before and after the observations. The instrument responses were removed from all seismograms used in the present study before measuring phase velocities.

\section{Methods}

We employed the two-station method of Isse et al. (2006) and Suetsugu et al. (2009) to measure dispersion curves of fundamental-mode Rayleigh waves. When two stations are located on approximately the same great circle from an earthquake, the phase velocity dispersion between stations can be determined by computing the phase differences of surface waves (Fig. 2). This method allows us to ignore the effects of phase shifts due to source excitation and lateral heterogeneities far outside the inter-station path. If the source location is far enough from the stations, the wave front of a surface wave can be treated as a plane wave. Under these conditions, the phase differences of surface waves between two stations are caused by the differential distance $\left(\mathrm{AB}^{\prime}\right)$ between a farther station $(\mathrm{A})$ and a point $\left(\mathrm{B}^{\prime}\right)$ projected from the nearer station (B) onto the great circle path (AE) from the source to the far station (Fig. 2), so that the measured phase velocities are averages over the differential distance $\left(\mathrm{AB}^{\prime}\right)$. We selected station pairs whose azimuthal differences from the source $(\alpha)$ were less than $5^{\circ}$, and this met the condition that the difference between the great circle distance from the event to the far station and the distance to the far station via the near station was less than $25 \mathrm{~km}$. To remove phase velocity measurements near the nodal directions of the surface wave radiation, we calculated radiation patterns at the source locations of fundamental mode of Rayleigh waves using the Global CMT. We used only data with a normalized radiated amplitude of $>0.4$. We then measured the phase velocity dispersion curves of fundamental Rayleigh waves for periods between 30 and $140 \mathrm{~s}$, whose RMS errors (Aki and Richards 2002) were less than $0.02 \mathrm{~km} / \mathrm{s}$.

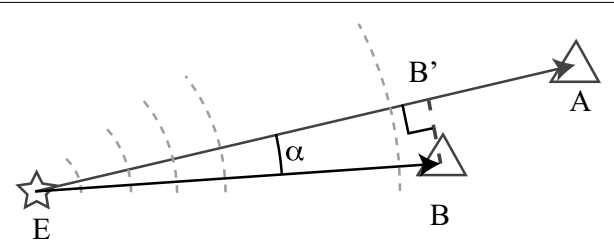

Fig. 2 Schematic diagram of the two-station method. $A, B$ Seismic stations. $E$ is the source location. $B^{\prime}$ is the projected point of $B$ on the $A E$ great circle. Gray broken lines indicate the Rayleigh wave front. Using the two-station method, the phase velocity between $A$ and $B^{\prime}$ is measured under the condition that the wave front propagates as a plane wave
A total of 1127-1934 surface wave paths were collected in this period range (Fig. 3a). The ray distributions of the obtained phase velocities are shown in Fig. 3b. We inverted the measured phase velocities between station pairs for two-dimensional phase velocity maps using a method developed by Montagner (1986), in which a smoothness constraint can be applied by introducing a covariance function.

In the present study, the covariance function $\left(C_{p}\right)$ is defined as

$$
C_{p}\left(M_{1}, M_{2}\right)=\sigma\left(M_{1}\right) \sigma\left(M_{2}\right) \exp \left[\frac{\cos \Delta-1}{L_{M_{1}} L_{M_{2}}}\right]
$$

where $\Delta$ is the distance between points $M_{1}$ and $M_{2}$ on the Earth's surface. The a priori parameter error $\sigma$ gives a constraint on the strength of the velocity perturbation. In constructing phase velocity maps with varying $\sigma$ values, we chose $0.10 \mathrm{~km} / \mathrm{s}$, which provides a best fit to the data. As patterns of obtained velocity maps with varying $\sigma$ are similar, the choice of $\sigma$ has little effect on our results except for the strength.

The correlation lengths $L_{M_{1}}, L_{M_{2}}$ control the smoothness of the model. Two correlation lengths (100 and $200 \mathrm{~km}$ ) were examined with synthetic data to determine an optimal value of correlation length. We then inverted the dispersion curves for the shear wave velocity model at each grid, using the linearized relationship between the

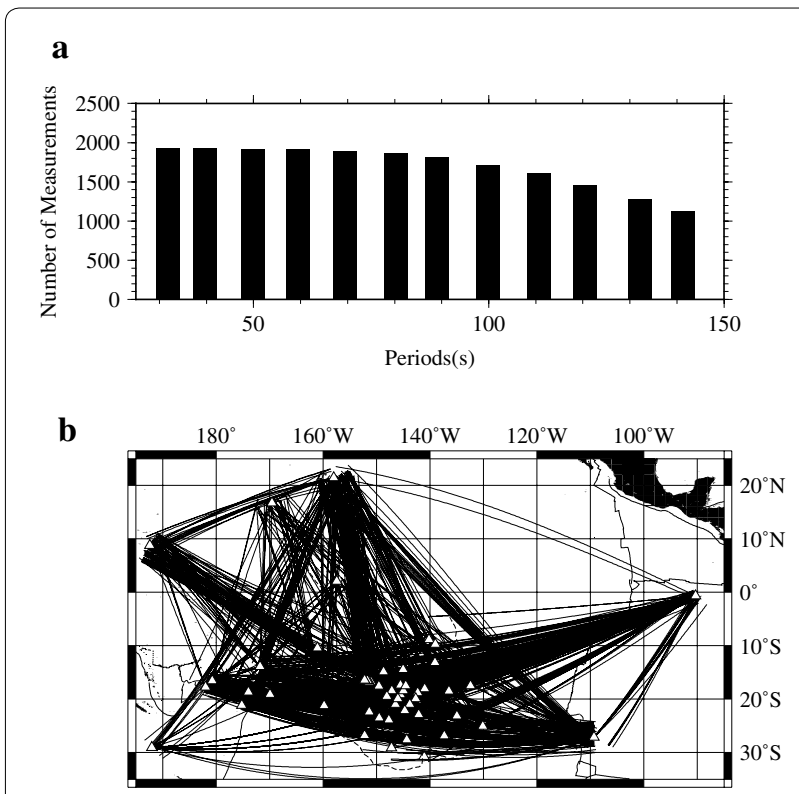

Fig. 3 Number of measured phase velocities and ray distributions. The number of phase velocity measurements in the present study as a function of period, between 30 and $140 \mathrm{~s}$ (a). The ray distribution at 100 s used in the present study (b) 
period dependence of surface wave phase velocity and the depth variation of shear wave velocity (e.g., Takeuchi and Saito 1972), as follows:

$$
\begin{aligned}
\frac{\delta c(\omega)}{c}= & \int_{0}^{R}\left\{K_{\rho}(\omega, z) \frac{\delta \rho(z)}{\rho}+K_{\alpha}(\omega, z) \frac{\delta \alpha(z)}{\alpha}\right. \\
& \left.+K_{\beta}(\omega, z) \frac{\delta \beta(z)}{\beta}\right\} \mathrm{d} z,
\end{aligned}
$$

where $\delta c$ is the perturbation of the phase velocity; $\delta \rho, \delta \alpha$, and $\delta \beta$ are the density, $P$-wave velocity, and shear wave velocity, respectively; $R$ is the radius of the Earth; and $K_{\rho}, K_{\alpha}$ and $K_{\beta}$ are sensitivity kernels, which represent the partial derivatives of phase velocity with respect to each model parameter. We fixed the density and $P$-wave velocity structure at the reference model's values and solved only for shear wave velocity, as the effects of density and $P$-wave velocity on Rayleigh wave phase velocity a $5^{\circ} \times 5^{\circ}$

$170^{\circ} \mathrm{W} \quad 160^{\circ} \mathrm{W} \quad 150^{\circ} \mathrm{W} \quad 140^{\circ} \mathrm{W} \quad 130^{\circ} \mathrm{W}$

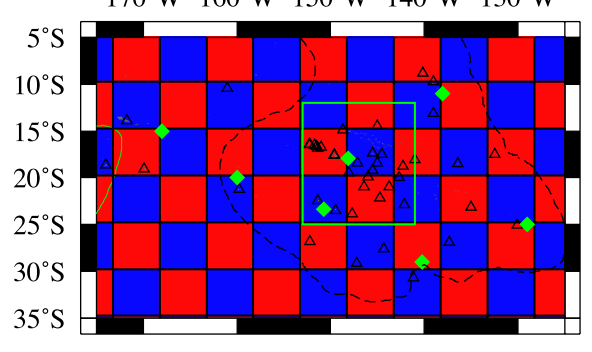

b $100 \mathrm{~km}$

$170^{\circ} \mathrm{W} 160^{\circ} \mathrm{W} 150^{\circ} \mathrm{W} 140^{\circ} \mathrm{W} 130^{\circ} \mathrm{W}$

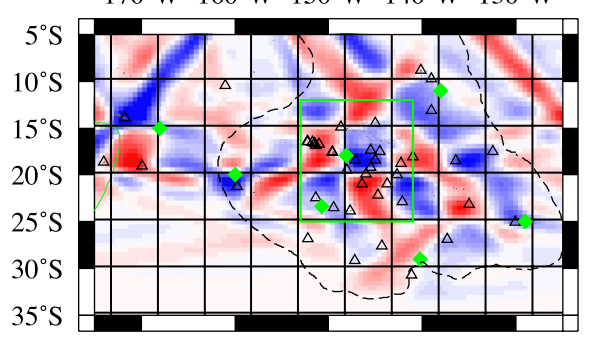

c $200 \mathrm{~km}$

$170^{\circ} \mathrm{W} \quad 160^{\circ} \mathrm{W} 150^{\circ} \mathrm{W} 140^{\circ} \mathrm{W} \quad 130^{\circ} \mathrm{W}$

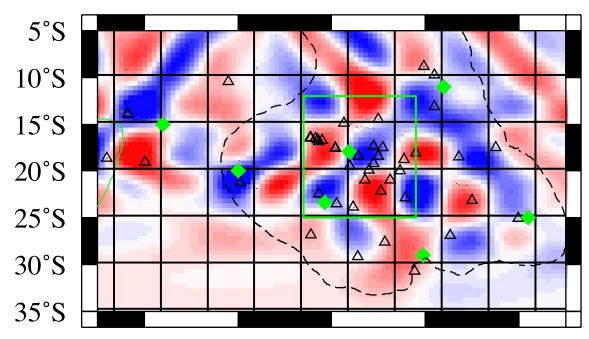

\section{d $3^{\circ} \times 3^{\circ}$}

$170^{\circ} \mathrm{W} 160^{\circ} \mathrm{W} 150^{\circ} \mathrm{W} 140^{\circ} \mathrm{W} 130^{\circ} \mathrm{W}$

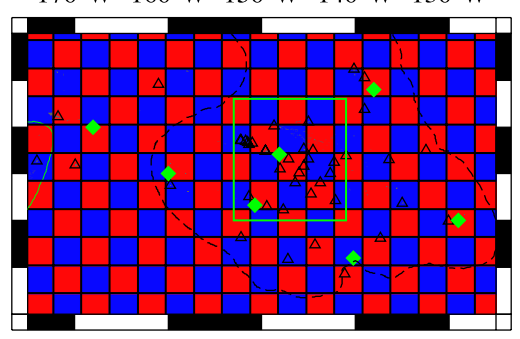

e $100 \mathrm{~km}$

$170^{\circ} \mathrm{W} \quad 160^{\circ} \mathrm{W} \quad 150^{\circ} \mathrm{W} \quad 140^{\circ} \mathrm{W} 130^{\circ} \mathrm{W}$

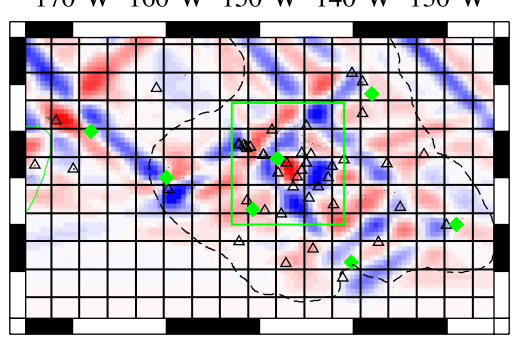

f $200 \mathrm{~km}$

$170^{\circ} \mathrm{W} \quad 160^{\circ} \mathrm{W} \quad 150^{\circ} \mathrm{W} \quad 140^{\circ} \mathrm{W} 130^{\circ} \mathrm{W}$
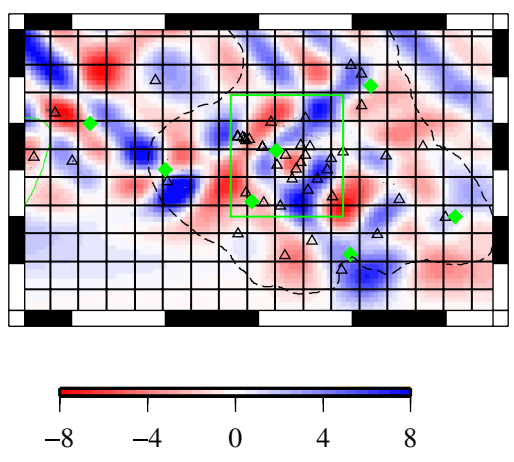

velocity perturbation, $\%$

Fig. 4 Results of a checkerboard resolution test for phase velocity distributions. We calculated the synthetic data from input checkerboard models with $8 \%$ anomalies at a period of $80 \mathrm{~s}$ : a, $\mathbf{d}$ input models, b, $\mathbf{c}, \mathbf{e}, \mathbf{f}$ output models. Cell sizes are $5^{\circ}$ and $3^{\circ}$ in $(\mathbf{a}-\mathbf{c})$ and $(\mathbf{d}-\mathbf{f})$, respectively. Correlation length is $100 \mathrm{~km}$ in $(\mathbf{b}, \mathbf{e})$ and $200 \mathrm{~km}$ in $(\mathbf{c}, \mathbf{f})$. Broken lines show the region of the superswell defined by depth anomalies greater than $300 \mathrm{~m}$. Open triangles indicate the stations, and green diamonds indicate active hotspots. Green rectangle outlines the "Society region," where a correlation length of $100 \mathrm{~km}$ is applied in Fig. 5 
perturbations are not significant (Nataf et al. 1986). The iterative least squares inversion technique proposed by Tarantola and Valette (1982) was used for the inversion; this nonlinear inversion procedure has been used in many previous surface wave studies (e.g., Nishimura and Forsyth 1989). Our reference one-dimensional model was modified from PREM (Dziewonski and Anderson 1981) by smoothing the $220-\mathrm{km}$ discontinuity. We adopted the CRUST2.0 model (Bassin et al. 2000) for the crust. We chose an a priori parameter error of $0.10 \mathrm{~km} / \mathrm{s}$ and an a priori data error of $0.05 \mathrm{~km} / \mathrm{s}$. Changing the a priori data error does not influence shear wave velocity models significantly. The vertical correlation length was $5 \mathrm{~km}$ at depths shallower than $30 \mathrm{~km}$, and $20 \mathrm{~km}$ at greater depths. In these calculations, we corrected an anelastic effect caused by the attenuation of seismic waves by using PREM, so that the reference frequency of the obtained model was $1 \mathrm{~Hz}$.

\section{Resolution test}

To assess the lateral resolution of tomographic models and select appropriate horizontal correlation lengths, we performed ray-theoretical checkerboard resolution tests. We calculated the synthetic data from input checkerboard models with $8 \%$ anomalies at a period of $80 \mathrm{~s}$, with a cell size that varied from $3^{\circ}$ to $8^{\circ}$. We added random errors with amplitudes up to $0.02 \mathrm{~km} / \mathrm{s}$, a value comparable to measured RMS errors, to the synthetic data. We then inverted the synthetic data for a two-dimensional phase velocity map using correlation lengths of 100 and $200 \mathrm{~km}$. Figure 4 shows a recovery of the input checkerboard pattern of $3^{\circ}$ and $5^{\circ}$. The $5^{\circ}$ checkerboard pattern is well recovered in the whole studied region with the correlation length of $200 \mathrm{~km}$ (Fig. 4c), except for the southwest region, where ray paths are sparse. Using a correlation length of $100 \mathrm{~km}$, the input pattern was well recovered in the vicinity of the Society hotspot (latitudes $12^{\circ}-25^{\circ} \mathrm{S}$ and longitudes $141^{\circ}-153^{\circ} \mathrm{W}$; herein called the "Society region") and in the vicinity of the Samoa hotspot, where seismic stations were densely distributed (Fig. 4b). On the other hand, the retrieved patterns were distorted outside the Society region (herein called "the outer region"). This suggests that a correlation length of $200 \mathrm{~km}$ is appropriate in the outer region, and the best possible resolution in the outer region is $\sim 5^{\circ}$.

Next, we investigated recovery of the checkerboard patterns with a cell size of $3^{\circ}$ (Fig. $4 \mathrm{e}, \mathrm{f}$ ). Using a correlation length of $200 \mathrm{~km}$, the recovered pattern was smeared throughout the whole studied region (Fig. 4f). A correlation length of $100 \mathrm{~km}$ yielded good recovery in the Society region, but the pattern was only poorly recovered in the outer region (Fig. $4 \mathrm{e}$ ).

Because our tests suggest that lateral resolution in the studied region is not uniform, a single choice of a correlation length may be inappropriate. Therefore, to optimize resolution in both the Society and outer regions, we use a correlation length of $100 \mathrm{~km}$ in the Society region and $200 \mathrm{~km}$ in the outer region. A third checkerboard test, using cell sizes of $3^{\circ}$ in the Society region and $5^{\circ}$ in the outer region (Fig. 5a), achieved satisfactory recovery in both regions (Fig. 5b). In the present study, we inverted for phase velocity maps using a correlation length of $100 \mathrm{~km}$ in the Society region and $200 \mathrm{~km}$ in the outer region.

The results of these checkerboard tests suggest that lateral resolution in the Society region is about $300 \mathrm{~km}$ and that in the outer region is $500 \mathrm{~km}$, which is a higher resolution than the previous studies achieved. The amplitude
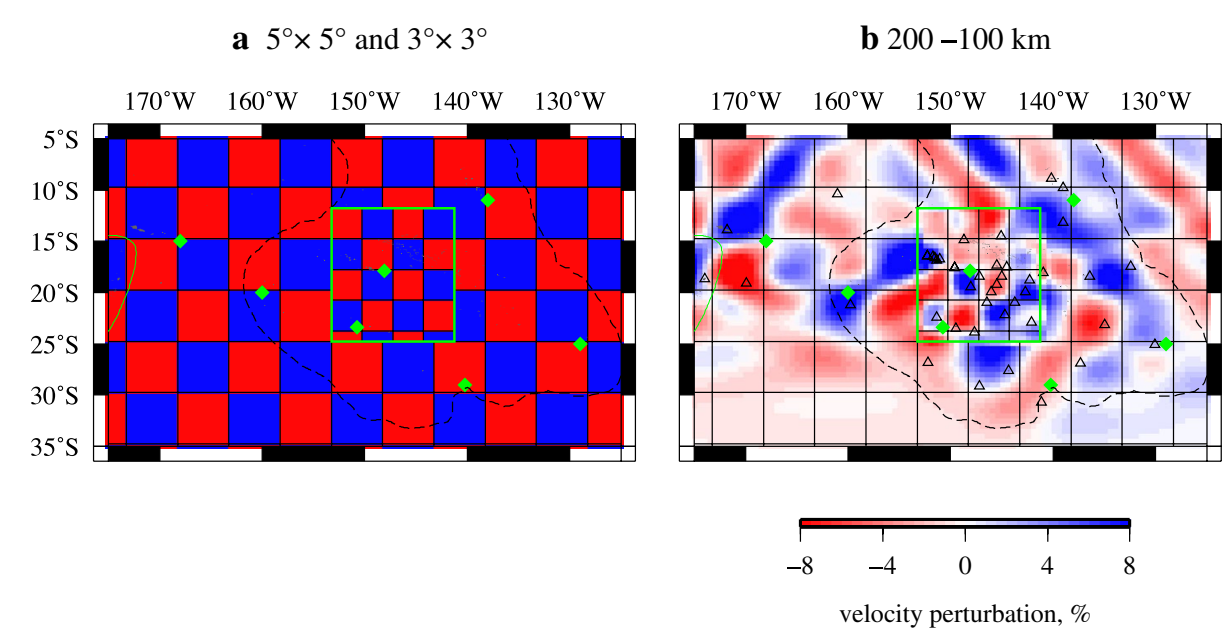

Fig. 5 Results of a checkerboard resolution test with $3^{\circ}$ and $5^{\circ}$ cells. The region of $3^{\circ}$ cells is indicated by the green rectangle (the Society region) in the central part of the figure. The other region (the outer region) has a cell size of $5^{\circ}$. a Input model, $\mathbf{b}$ output model with a correlation length of $100 \mathrm{~km}$ in the Society region and $200 \mathrm{~km}$ in the outer region. Symbols are as in Fig. 4 

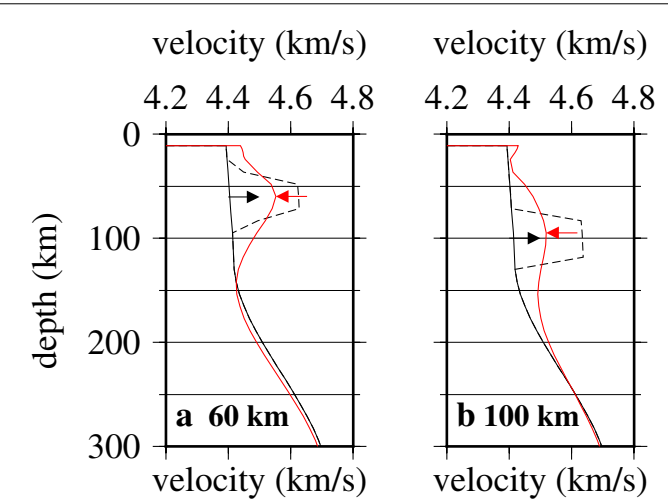

velocity $(\mathrm{km} / \mathrm{s})$

velocity $(\mathrm{km} / \mathrm{s})$

$\begin{array}{llll}4.2 & 4.4 & 4.6 & 4.8\end{array}$

$\begin{array}{llll}4.2 & 4.4 & 4.6 & 4.8\end{array}$

$\begin{array}{llll}4.2 & 4.4 & 4.6 & 4.8\end{array}$
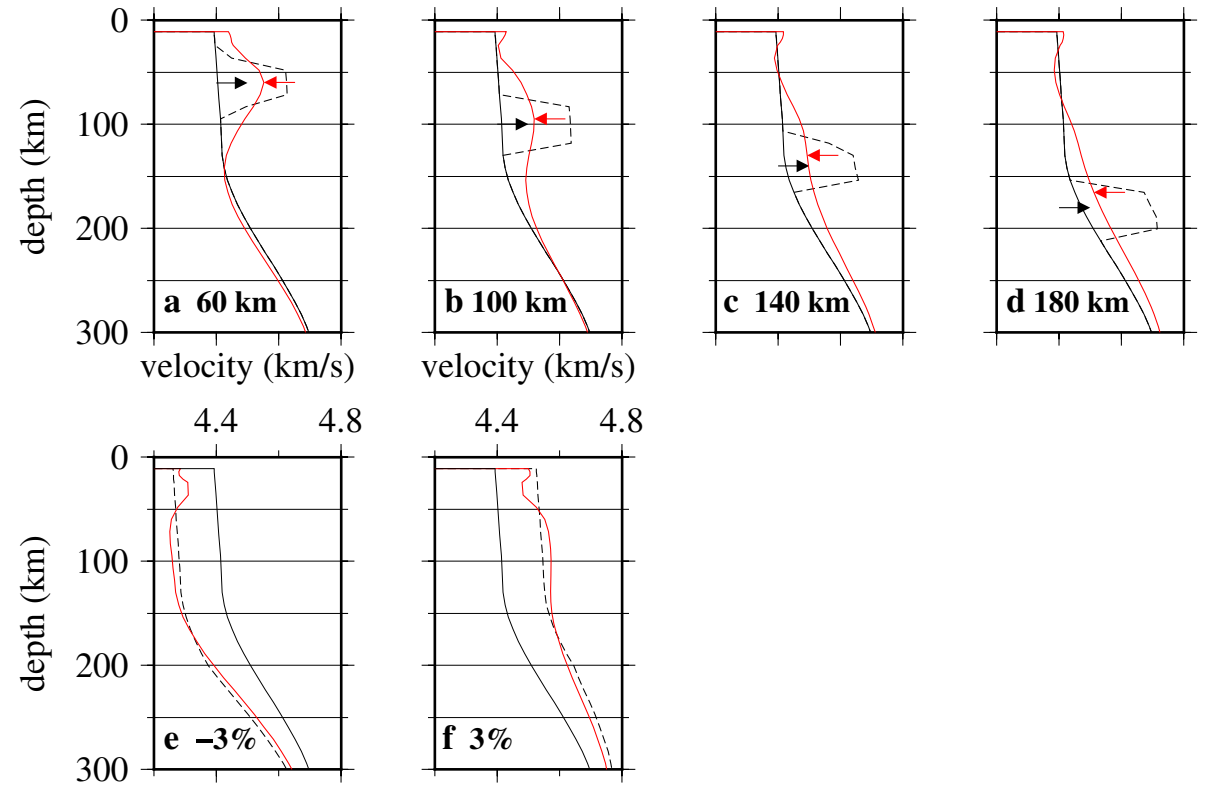

Fig. 6 Results of vertical resolution test for shear wave velocity models. Dashed lines indicate the input model used to calculate synthetic phase velocities. Black lines indicate initial models in the inversion. Red lines indicate retrieved shear wave velocity models. Result of spike test at depths of a $60 \mathrm{~km}, \mathbf{b} 100 \mathrm{~km}, \mathbf{c} 140 \mathrm{~km}$, and $\mathbf{d} 180 \mathrm{~km}$ is shown. e Vertical resolution test with an initial model uniformly $3 \%$ slower than the input model. f as (e), for an initial model $3 \%$ faster. Black arrows show the center of the input spike and red arrows show the depth where the difference between the initial and retrieved models is the maximum
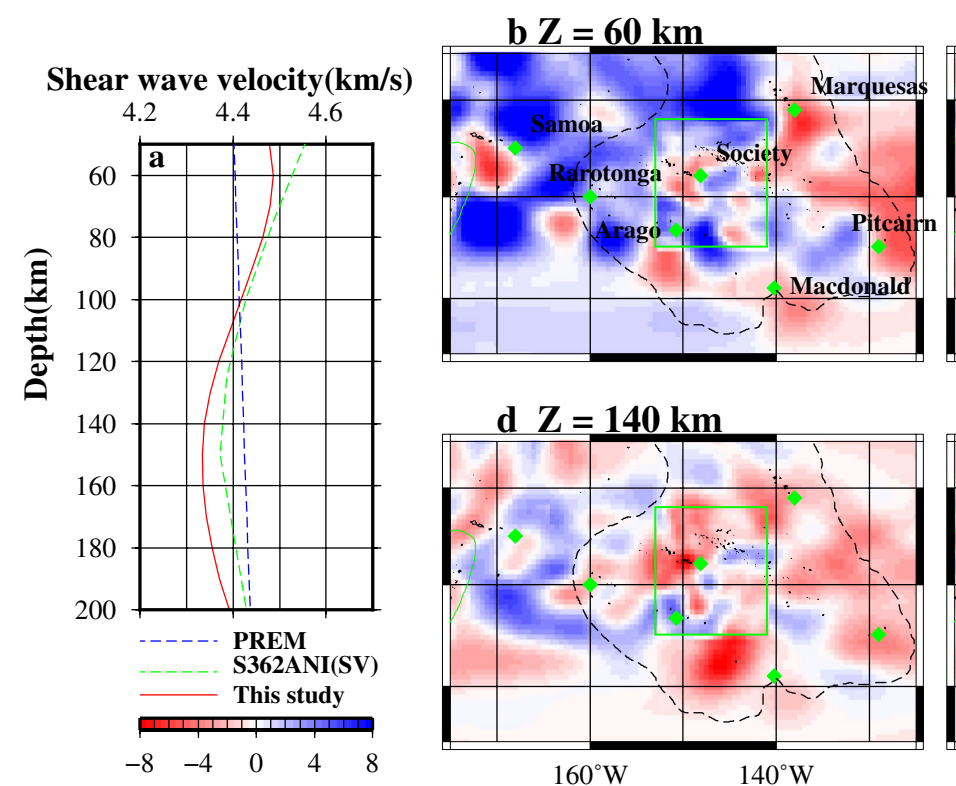

\section{c $Z=100 \mathrm{~km}$}

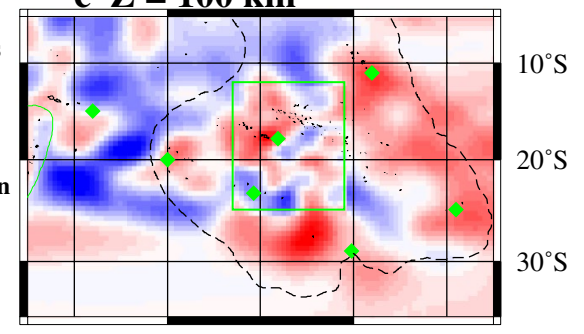

d $Z=140 \mathrm{~km}$

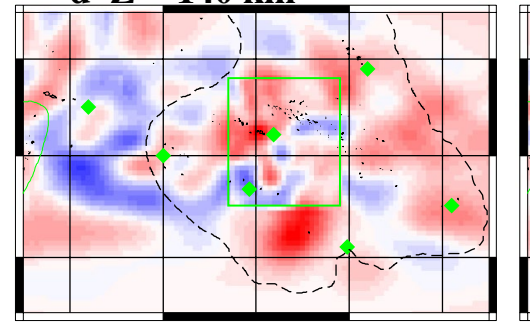

$160^{\circ} \mathrm{W}$

$140^{\circ} \mathrm{W}$ e $\mathrm{Z}=180 \mathrm{~km}$

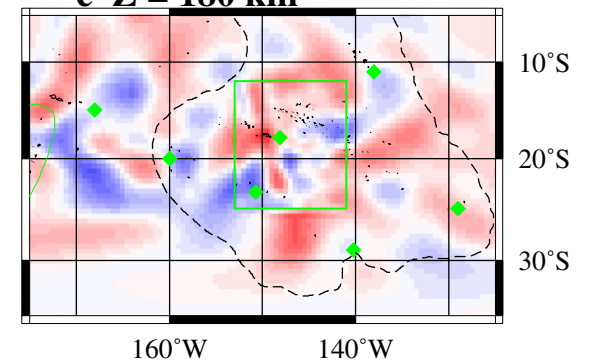

velocity perturbation, $\%$

Fig. 7 Shear wave model in the upper mantle beneath the studied region of the South Pacific. a Red line indicates the reference shear wave velocity in the present study, which is averaged shear wave velocity profile in the superswell region in the studied region. Green broken line indicates SV velocity profile of the superswell region created from S362ANI, and blue broken line indicates PREM which is the initial model in the mantle. The reference frequency of these profiles is $1 \mathrm{~Hz}$. Map projections are shown of shear wave velocity structures at depths of b $60 \mathrm{~km}$, c $100 \mathrm{~km}$, d $140 \mathrm{~km}$, and e $180 \mathrm{~km}$. Symbols are as in Fig. 4 
of the recovered patterns is also better in the present study. The dense coverage of the TIARES network in the Society region is likely to contribute to the improvement of the horizontal resolution.

To assess the vertical resolution of the model, we performed spike tests (Fig. 6a-d). We created four synthetic models (dashed lines in Fig. 6) with $5 \%$ fast anomalies in a narrow depth range of $60-180 \mathrm{~km}$. We calculated synthetic phase velocities of Rayleigh waves from these models and inverted for shear wave profiles (red solid lines in Fig. 6). Although the shapes of the recovered spikes are vertically smeared, due to the long wavelength of the surface waves, the input anomaly is well recovered for the target depths of 60 and $100 \mathrm{~km}$. At depths of 140 and $180 \mathrm{~km}$, the shape of the recovered spike is largely smeared out, so the vertical resolution at these depths is worse than that at shallower depths.

To assess the sensitivity to the initial model, we created a synthetic model using a modified PREM with a seafloor depth of $4.2 \mathrm{~km}$, crustal thickness of $6.6 \mathrm{~km}$, and $\pm 3 \%$ uniform velocity perturbations. The results suggest that shear wave velocities at depths shallower than $50 \mathrm{~km}$ are not well recovered if the initial model is substantially different from the synthetic model (Fig. 6e, f). Rayleigh waves in the range of periods analyzed are less sensitive to such depths, so final models resemble the initial model at shallow depths. Small misfits to the synthetic models, less than $0.03 \mathrm{~km} / \mathrm{s}$, are also observed at depths greater than $50 \mathrm{~km}$, which compensate the misfits shallower than $50 \mathrm{~km}$. In the present study, we focus on shear wave models at depths greater than $50 \mathrm{~km}$.

\section{Results}

We obtained three-dimensional shear wave velocity models of the upper mantle at depths shallower than $200 \mathrm{~km}$ from two-dimensional phase velocity maps. Figure 7 shows the three-dimensional shear wave velocity structure in the upper mantle beneath the studied region (latitudes $5^{\circ}-35^{\circ} \mathrm{S}$, longitudes $125^{\circ}-175^{\circ} \mathrm{W}$ ). To investigate the average features of velocity anomalies in

a $Z=100 \mathrm{~km}$
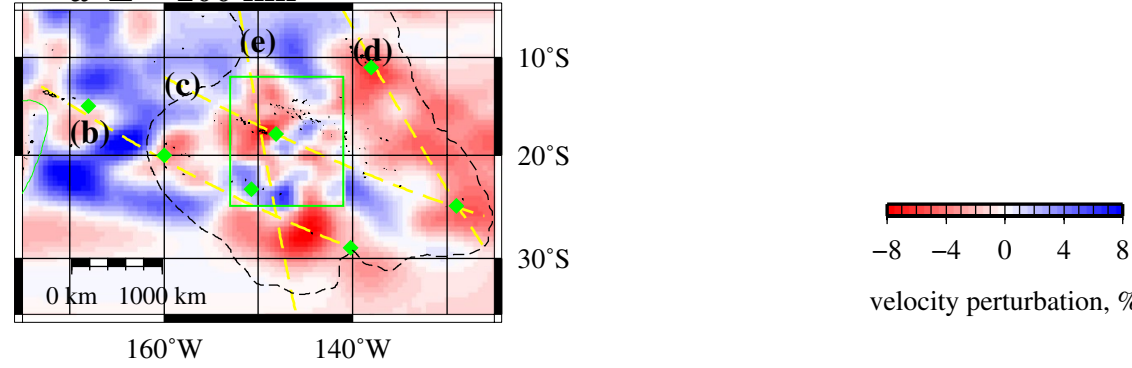

velocity perturbation, $\%$

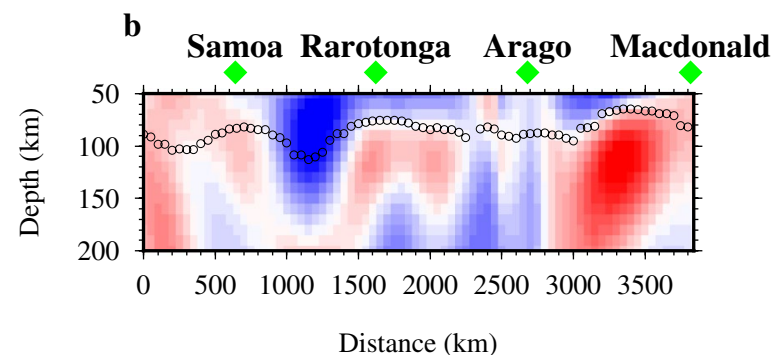

c

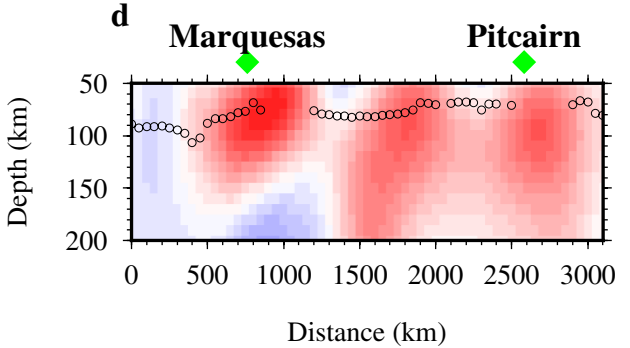

$\mathbf{e}$

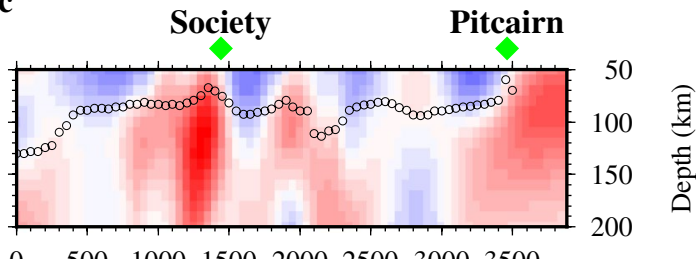

$0 \quad 500 \quad 1000 \quad 1500 \quad 2000 \quad 2500 \quad 3000 \quad 3500$

Distance $(\mathrm{km})$
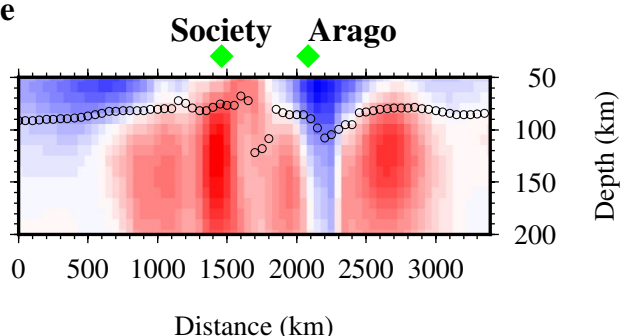

Distance $(\mathrm{km})$

Fig. 8 Vertical profiles of the shear wave velocity model. a Map projection at a depth of $100 \mathrm{~km}$ (same as Fig. 7c). Yellow broken lines indicate the locations of profiles. b Profile along the Cook-Austral to Samoa hotspot trail. c Profile along the Society to Pitcairn trail. d Profile along Marquesas and Pitcairn hotspots. e Profile between the Society and Arago hotspots. Circles indicate the depth of the lithosphere-asthenosphere boundary estimated from the maximum depth of the negative vertical gradient of shear wave velocity 
the superswell, we compared a one-dimensional average velocity profile beneath the superswell region in the studied region, where seafloor age is between 20 and $112 \mathrm{Ma}$ after Muller et al. (2008) (region surrounded by broken lines in Fig. 7), with a profile from outside of the superswell region (Northern Hemisphere Pacific seafloor, with ages between 20 and $112 \mathrm{Ma}$ ), created from a global tomographic model (S362ANI; Kustowski et al. 2008). The two profiles are different by $0.05 \mathrm{~km} / \mathrm{s}$ at most, suggesting that the superswell region has no uniformly slow anomaly. This is consistent with previous studies (Isse et al. 2006; Suetsugu et al. 2009).

In the upper $100 \mathrm{~km}$, the westward increase in shear wave velocity can be seen as a large-scale lateral variation, which is associated with the cooling of the Pacific plate with age (Fig. $7 \mathrm{~b}, \mathrm{c}$ ). There are slow anomalies near the Society, Pitcairn, Macdonald, and Samoa hotspots at depths down to $180 \mathrm{~km}$, while slow anomalies southwards of the Arago hotspots are confined to shallower depths, and slow anomalies beneath the Rarotonga hotspot are confined to greater depths (Fig. 7b-e). These features, except for the Rarotonga and Samoa hotspots, are consistent with previous models (Isse et al. 2006; Suetsugu et al. 2009). The surface wave tomography model of Maggi et al. (2006), created with land-based and the PLUME data, also showed deep-rooted slow anomalies beneath the Society and Macdonald hotspots, extending to the mantle transition zone. The slow anomalies of Marquesas were shallower than $150 \mathrm{~km}$ in their model.

Vertical profiles of hotspots are shown in Fig. 8. The anomaly beneath the Marquesas hotspot appears shallow-rooted compared with the Society and Macdonald hotspots. The slow anomalies beneath the Society and Macdonald hotspots are found down to depths of $200 \mathrm{~km}$ or more, whereas those beneath Marquesas are confined to depths less than $160 \mathrm{~km}$ (Fig. 8b-d), consistent with previous studies. New results of the present study are that the slow anomalies beneath Rarotonga hotspot are at depths greater than $80 \mathrm{~km}$, that the Arago hotspot has weak or no anomalies, and that slow anomalies near the Samoa hotspot extend to $200 \mathrm{~km}$ (Fig. 8b). The slow anomaly beneath the Society hotspot has a narrower and more vertically oriented profile compared with previous studies (Fig. 5c in Suetsugu et al. 2009, Fig. 4g in Isse et al. 2006). Some slow anomalies are apparently unassociated with any hotspot. The vertical profile along the Marquesas and Pitcairn hotspots, which does not lie along the hotspot trail, shows three slow anomalies, the middle of which is deep-rooted but not connected to any surface hotspot (Fig. 8d). Another deep-rooted slow velocity anomaly without a corresponding surface hotspot is located between the Society and Pitcairn hotspots (Fig. 8c), and a third can be seen in the south of the

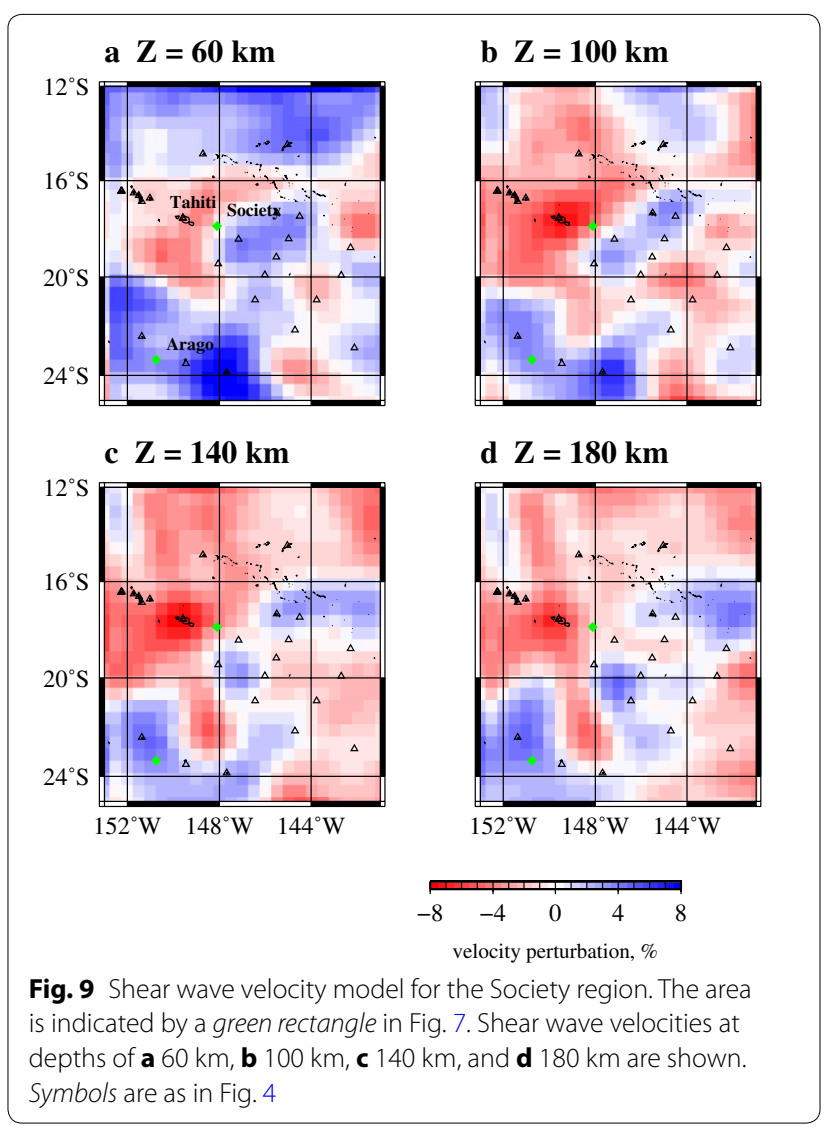

Cook-Austral chain between the Macdonald and Arago hotspots (Fig. 8b, e). The former is the site where Niu et al. (2002) and Suetsugu et al. (2009) found a substantially thin (presumably hot) mantle transition zone. These orphaned anomalies may represent mantle plumes that have not yet reached the surface, and they remain to be studied in future work.

\section{Discussion}

We focus on the seismic anomalies in the Society region, where ray coverage allows us to use the smaller correlation length of $100 \mathrm{~km}$. Figure 9 shows the shear wave velocity models in the region. We can see a slow anomaly zone near the Society hotspot, whose center ( $6 \%$ slow) is located beneath Tahiti island, and no slow anomalies beneath the Arago hotspot, where fast anomalies exist. The Society hotspot is located at one edge of the slow anomalies. These anomalies are $\sim 300 \mathrm{~km}$ in diameter, which is comparable to the lateral resolution of the checkerboard test. At depths of 140 and $180 \mathrm{~km}$, we found a strong slow anomaly of about $5 \%, 400 \mathrm{~km}$ to the south of the Society hotspot, with a lateral extent of $200-300 \mathrm{~km}$; however, the size of this anomaly is comparable to, or slightly smaller than, the minimum lateral resolution of 


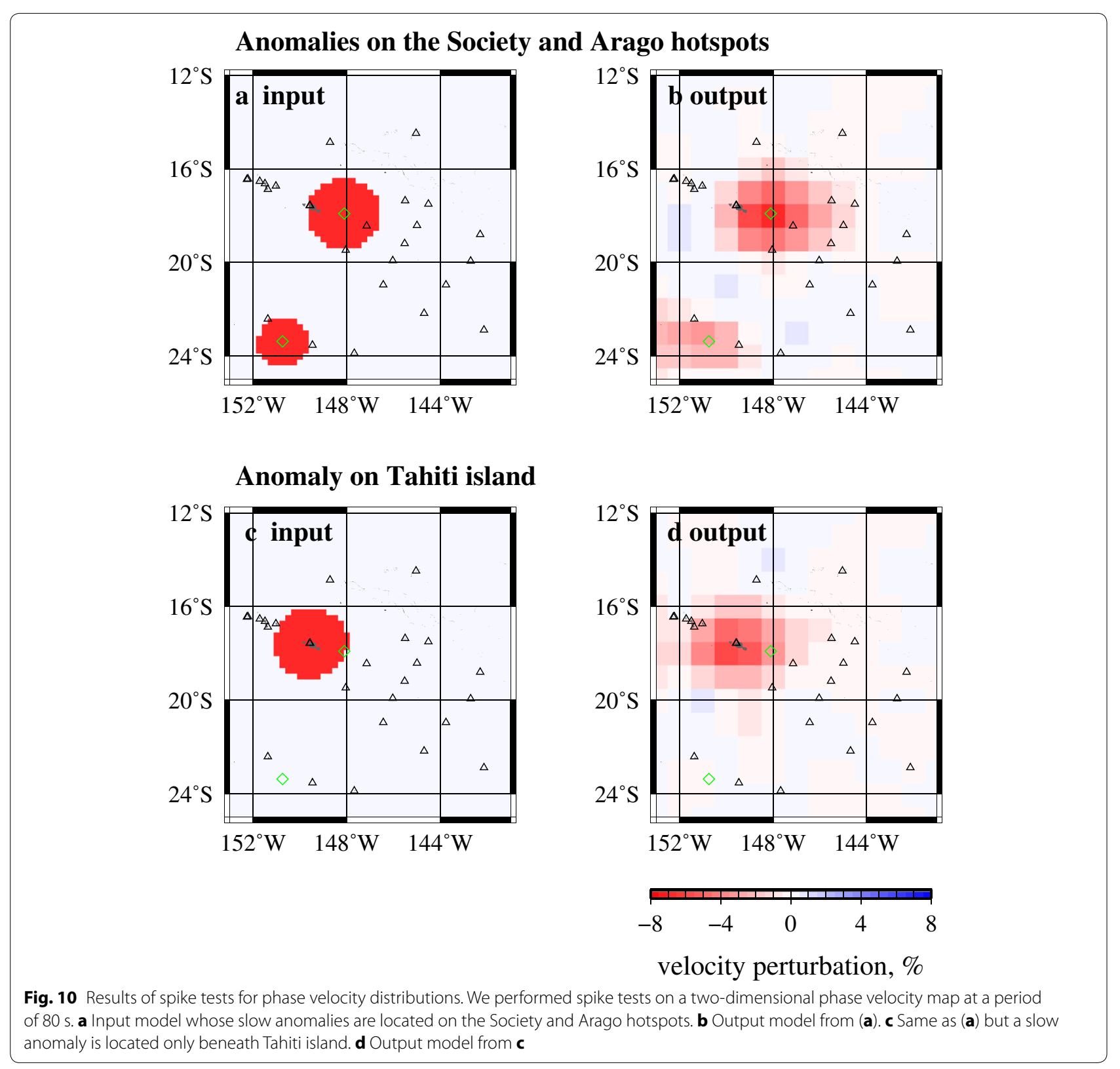

our checkerboard test. To examine whether the locations of the slow anomalies are well constrained, we performed spike tests on a two-dimensional phase velocity map at a period of $80 \mathrm{~s}$ by calculating the synthetic data from two input models: One has slow anomalies beneath the Society (300 km in diameter) and Arago (200 km in diameter) hotspots (Fig. 10a, b) and the other has a slow anomaly beneath Tahiti island (300 km in diameter) (Fig. 10c, d). All the anomalies are $-7 \%$ and random errors with amplitudes up to $0.02 \mathrm{~km} / \mathrm{s}$, a value comparable to measured RMS errors, were added to the synthetic data. In both cases, recovered anomalies were located on the same locations of the input models, suggesting that the lateral resolution is sufficient to resolve location of the two anomalies. Figure 8e shows a vertical profile across these two slow anomalies. The slow anomalies appear to merge with those immediately beneath the Society hotspot (and Tahiti island) at depths shallower than $100 \mathrm{~km}$.

Next, we examine effects of correlation lengths on the lateral heterogeneities imaged in the Society region. Figure 11a, b, d, and e shows that velocity anomalies imaged with a correlation length of $100 \mathrm{~km}$ are all presented in the images obtained with a correlation length $200 \mathrm{~km}$. The only noticeable difference is that the slow anomalies are more localized when a correlation length of $100 \mathrm{~km}$ is used. The lateral velocity variation patterns 
a $Z=100 \mathrm{~km}(\mathrm{~L}=200 \mathrm{~km})$

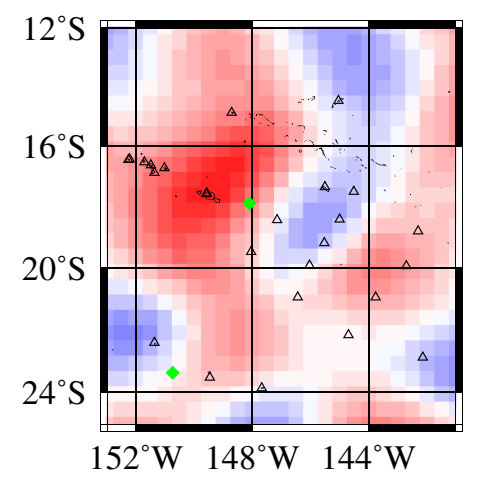

b $Z=100 \mathrm{~km}(L=100 \mathrm{~km})$

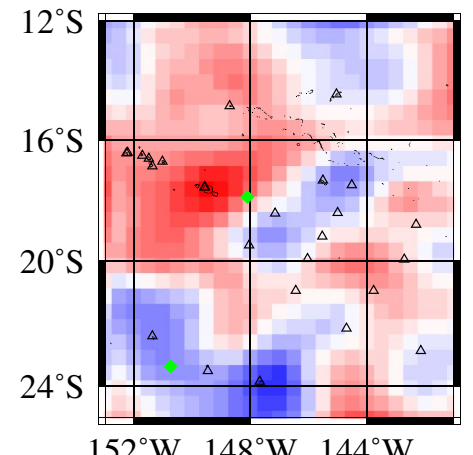

c $Z=100$ km (Suetsugu et al., 2009)

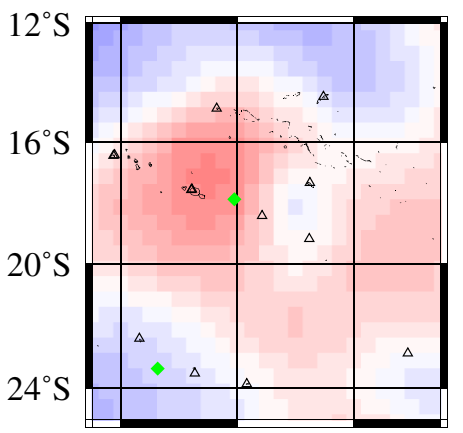

$152^{\circ} \mathrm{W} \quad 148^{\circ} \mathrm{W} 144^{\circ} \mathrm{W}$ d $Z=140 \mathrm{~km}(\mathrm{~L}=200 \mathrm{~km})$

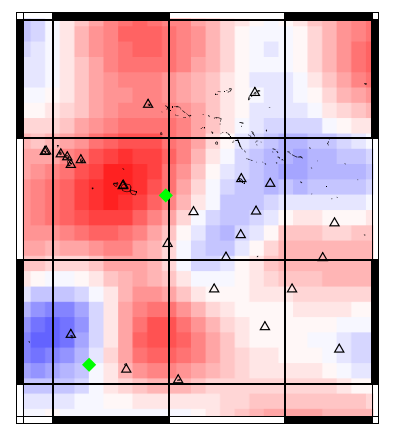

$152^{\circ} \mathrm{W} \quad 148^{\circ} \mathrm{W} \quad 144^{\circ} \mathrm{W}$

e $Z=140 \mathrm{~km}(\mathrm{~L}=100 \mathrm{~km})$

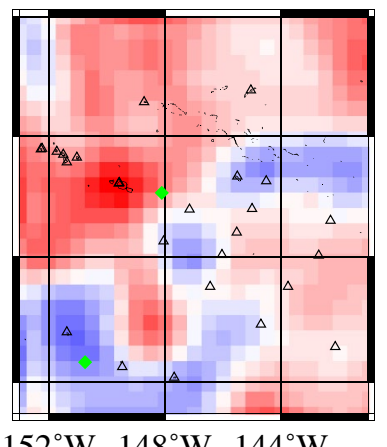

$152^{\circ} \mathrm{W} \quad 148^{\circ} \mathrm{W} 144^{\circ} \mathrm{W}$

f $Z=140 \mathrm{~km}$ (Suetsugu et al., 2009)

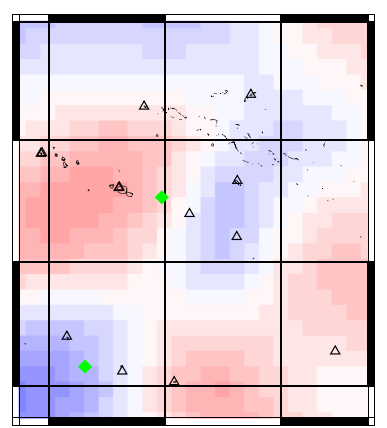

$152^{\circ} \mathrm{W} \quad 148^{\circ} \mathrm{W} 144^{\circ} \mathrm{W}$

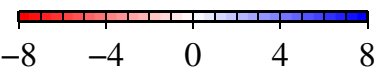

velocity perturbation, $\%$

Fig. 11 Effects of correlation lengths on the lateral heterogeneities imaged in the Society region. Shear wave velocity maps of obtained with correlation lengths (L) of $\mathbf{a}, \mathbf{d} 200 \mathrm{~km}$ and $\mathbf{b}, \mathbf{e} 100 \mathrm{~km}$ at depths of $\mathbf{a}, \mathbf{b} 100 \mathrm{~km}$ and $\mathbf{d}, \mathbf{e} 140 \mathrm{~km}$ are compared. Previous results at depths of $\mathbf{c} 100 \mathrm{~km}$ and $140 \mathrm{~km}$ (from Suetsugu et al. 2009) are also shown. Symbols are as in Fig. 4

in Fig. 9 are therefore robust with respect to the choice of correlation length.

Figure $11 \mathrm{~b}, \mathrm{c}$, e, f compares the velocity anomalies obtained in the present study with those obtained by
Suetsugu et al. (2009). Although the Rayleigh wave tomography employed by Suetsugu et al. (2009) is not exactly identical to that of the present study, differences between the two studies are caused mainly by the better path coverage 


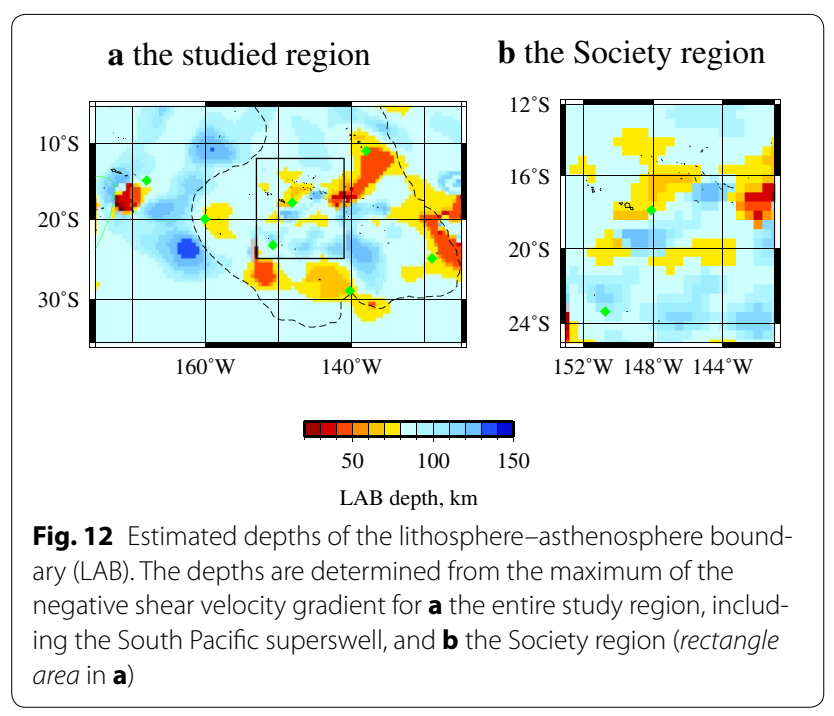

of the present study. Compared with Suetsugu et al. (2009), a substantial improvement in lateral resolution is achieved with data from the TIARES experiment. As the figures show, the slow velocity anomalies are more localized in the present study. The large-scale anomaly patterns found by Suetsugu et al. (2009) (e.g., slow anomalies beneath Tahiti island and the Society hotspot, and those east of the Society hotspot) are preserved in the present study. More localized slow anomalies, such as that located at $400 \mathrm{~km}$ south of the Society hotspot, were not detected by Suetsugu et al. (2009). The amplitudes of the velocity variations in the present study are 2-3 times as large as those in Suetsugu et al. (2009), which may be due to the new TIARES data, and/or the use of different inversion techniques.

Finally, we address the issue of interactions between mantle plumes and the lithosphere by estimating the depth of the lithosphere-asthenosphere boundary (LAB). While the limited depth resolution of surface waves makes it difficult to determine LAB depth directly, recent surface wave tomography work suggests that the maximum of the negative vertical gradient of shear wave velocity is a good proxy for LAB depth (Burgos et al. 2014). Figure 12 shows the $L A B$ depths thus determined. The average $L A B$ depth in the entire studied region is $\sim 90 \mathrm{~km}$. Shallow LAB depths are found near all hotspots in this region and are well correlated with slow shear wave anomalies at depths of $60 \mathrm{~km}$. LAB depths shallower than $50 \mathrm{~km}$ may be an artifact due to poor resolution of Rayleigh waves at the periods used in the present study for the depths shallower than $50 \mathrm{~km}$, as indicated by Fig. 6e. Hereafter, we discuss areas whose LAB depths exceed $50 \mathrm{~km}$. The LAB depths near the slow anomalies, irrespective of the existence of hotspots, are about $70 \mathrm{~km}$, i.e., nearly $20 \mathrm{~km}$ shallower than those in the surrounding area (Figs. $8 \mathrm{~b}-\mathrm{e}, 12$ ). The question may arise as to whether LAB depths in slow velocity regions may be necessarily estimated as shallow due to the artifact by the proxy of LAB depths. To address this possibility, we performed a series of synthetic tests, in which $L A B$ depths varied from 50 to $80 \mathrm{~km}$ and synthetic models had uniformly slower velocities than the initial model (Fig. 13). We found that the LAB depths were correctly determined by the proxy and not estimated as shallow. This suggests that the shallower LAB depths in the slow anomaly regions are not artificial. The shallow LAB depths near the slow anomalies may be evidence of thermal erosion of the lithosphere by mantle plumes (e.g., Detrick and Crough 1978). It is desirable to analyze higher-mode Rayleigh waves to obtain a definitive conclusion on this issue.

\section{Conclusions}

We deployed temporary seafloor broadband seismic instruments around the Society hotspot in the South Pacific superswell as a part of the TIARES project. We obtained

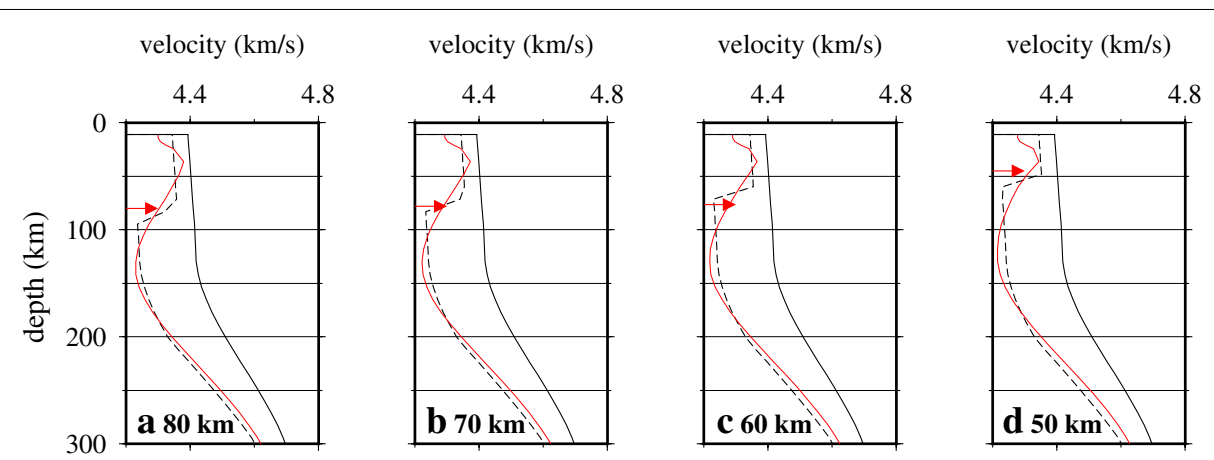

Fig. 13 Results of synthetic tests for $L A B$ depths. Synthetic models have $4 \%$ slow velocities than the initial model and $L A B$ depth at a $80 \mathrm{~km}$, b $70 \mathrm{~km}, \mathbf{c} 60 \mathrm{~km}$, and $\mathbf{d} 50 \mathrm{~km}$. Lithosphere is $1 \%$ slow velocities than the initial model. Lines are as in Fig. 6. Red arrows show the estimated LAB depths from the maximum of the negative shear wave velocity gradient 
an unprecedentedly high-resolution shear wave velocity model for the upper mantle in the region, using TIARES data combined with data from permanent and other temporary (island and seafloor) networks. The use of TIARES data resulted in improved ray coverage, especially in the region around the Society hotspot, thereby enabling finerscale mapping with surface wave tomography. The resolved structure reveals localized slow anomalies associated with nearby hotspots. The slow anomalies beneath the Samoa, Macdonald, Pitcairn, and Society hotspots extend at least down to a depth of $200 \mathrm{~km}$ and those of the Marquesas hotspot to $\sim 150 \mathrm{~km}$. The anomalies around the Society hotspot and $400 \mathrm{~km}$ south of the Society hotspot have a lateral extent of $\sim 300 \mathrm{~km}$. Several slow anomaly areas are apparently not associated with any hotspots; these may become the sites of future hotspots or represent failed hotspots. The LAB depths, estimated from the negative gradient of shear wave velocities, suggest that the lithosphere is thinned by $\sim 20 \mathrm{~km}$ in the vicinity of all hotspots, which may represent thermal erosion due to mantle plumes.

\begin{abstract}
Abbreviations
BBOBS: broadband ocean-bottom seismometer; LAB: lithosphere-asthenosphere boundary; PLUME: Polynesian Lithosphere and Upper Mantle Experiment; TIARES: Tomographic Investigation by seafloor ARray Experiment for the Society hotspot.
\end{abstract}

\section{Authors' contributions}

TI performed the observations by BBOBS, the data processing, and the analysis. H Sugioka, H Shiobara, and Al performed the observations by BBOBS. DR supported the observations by BBOBS and data collection by CEA stations. DS performed the observations by BBOBS, helped write the manuscript, and organized the TIARES project. All authors read and approved the final manuscript.

\section{Author details \\ ${ }^{1}$ Earthquake Research Institute, The University of Tokyo, 1-1-1 Yayoi, Bunkyo-ku, Tokyo 113-0032, Japan. ${ }^{2}$ Department of Planetology, Gradu- ate School of Science, Kobe University, 1-1 Rokkodai-cho, Nada-ku, Kobe, Hyogo 657-8501, Japan. ${ }^{3}$ Department of Deep Earth Structure and Dynam- ics Research, Japan Agency for Marine-Earth Science and Technology, 2-15 Natsushima-cho, Yokosuka, Kanagawa 237-0061, Japan. ${ }^{4}$ Laboratoire de Géophysique CEA/DASE/LDG, BP 640, 98713 Papeete, French Polynesia.}

\begin{abstract}
Acknowledgements
We thank the staff of IRIS, Geoscope, SPANET, CEA, Geoscience Australia, and the GEOFON data center for their efforts in maintaining and managing the seismic stations. We thank Noriko Tada, Kiyoshi Baba, and Takafumi Kasaya for their help during the installation and recovery cruises of the seafloor experiment and thank Natsue Abe for organizing the installation cruise. We are grateful to Pierre Mery and Jean-Pierre Barriot for their kind support in Tahiti. We also thank the editor and two anonymous reviewers for critical reviews of the manuscript. This work was supported by a Grant-in-Aid for Scientific Research (KAKENNHI, 19253004) from the Japan Society for the Promotion Science. The GMT software package (Wessel and Smith 1991) and SAC2000 (Goldstein and Minner 1996) were used in the present study.
\end{abstract}

\section{Competing interests}

The authors declare that they have no competing interests.

Received: 1 September 2015 Accepted: 11 February 2016 Published online: 29 February 2016

\section{References}

Adam C, Bonneville A (2005) Extent of the South Pacific super-swell. J Geophys Res 110:B09408. doi:10.1029/2004JB003465

Aki K, Richards PG (2002) Quantitative seismology, 2nd edn. University Science Books, Sausalito

Barruol G, Bosch D, Clouard V, Debayle E, Doin MP, Fontaine F, Godard M, Masson F, Reymond D, Tommasi A, Thoraval C (2002) PLUME investigates South Pacific superswell. Eos Trans AGU 83(45):511, 514

Bassin C, Laske G, Masters G (2000) The current limits of resolution for surface wave tomography in North America. Eos Trans AGU 81(48). Fall Meet. Suppl., Abstract S12A-03

Burgos G, Montagner JP, Beucler E, Capdeville Y, Mocquet A, Drilleau M (2014) Oceanic lithosphere-asthenosphere boundary from surface wave dispersion data. J Geophys Res 119(2):1079-1093. doi:10.1002/2013JB010528

Detrick RS, Crough ST (1978) Island subsidence, hot spots, and lithospheric thinning. J Geophys Res 83:1236-1244

Dziewonski AM, Anderson DL (1981) Preliminary reference Earth model. Phys Earth Planet Inter 25:297-356

Goldstein P, Minner L (1996) SAC2000: seismic signal processing and analysis tools for the 21st century. Seismol Res Lett 67:39

Ishida M, Maruyama S, Suetsugu D, Matsuzaka S, Eguchi T (1999) Superplume project: towards a new view of whole Earth dynamics. Earth Planets Space 51:1-5

Isse T, Suetsugu D, Shiobara H, Sugioka H, Yoshizawa K, Kanazawa T, Fukao Y (2006) Shear wave speed structure beneath the South Pacific superswell using broadband data from ocean floor and islands. Geophys Res Lett 33:L16303. doi:10.1029/2006GL026872

Isse T, Takeo A, Shiobara H (2014) Time correction and clock stability of ocean bottom seismometer using recorded seismograms. JAMSTEC Rep Res Dev 19:19-28 (in Japanese with English abstract)

Kustowski B, Ekström G, Dziewonski AM (2008) Anisotropic shear-wave velocity structure of the Earth's mantle: a global model. J Geophys Res 113:B06306. doi:10.1029/2007JB005169

Maggi A, Debayle E, Priestley K, Barruol G (2006) Multi-mode surface waveform tomography of the Pacific Ocean: a closer look at the lithospheric cooling signature. Geophys J Int 166:1384-1397. doi:10.1111/j.1365-246X.2006.03037.x

McNutt M (1998) Superswells. Rev Geophys 36:211-244

Montagner JP (1986) Regional three-dimensional structures using long-period surface waves. Ann Geophys 4:283-294

Muller RD, Sdrolias M, Gaina C, Roest WR (2008) Age, spreading rates, and spreading asymmetry of the world's ocean crust. Geochem Geophys Geosyst 9:Q04006. doi:10.1029/2007GC001743

Nataf HC, Nakanishi I, Anderson DL (1986) Measurements of mantle wave velocities and inversion for lateral heterogeneities and anisotropy: 3 . Inversion. J Geophys Res 91(B7):7261-7307

Nishimura CE, Forsyth DW (1989) The anisotropic structure of the upper mantle in the Pacific. Geophys J 96:203-229

Niu F, Solomon SC, Silver PG, Suetsugu D, Inoue H (2002) Mantle transitionzone structure beneath the South Pacific superswell and evidence for a mantle plume underlying the Society hotspot. Earth Planet Sci Lett 198:371-380

Suetsugu D, Shiobara H, Sugioka H, Barruol G, Schindele F, Reymond D, Bonneville A, Debsyle E, Isse T, Kanazawa T, Fukao Y (2005) Probing South Pacific mantle plumes with broadband OBS. Eos Trans AGU 86(44):429, 435

Suetsugu D, Isse T, Tanaka S, Obayashi M, Shiobara H, Sugioka H, Kanazawa T, Fukao Y, Barruol G, Reymond D (2009) South Pacific mantle plumes imaged by seismic observation on islands and seafloor. Geochem Geophys Geosyst 10:Q11014. doi:10.1029/2009GC002533

Suetsugu D, Shiobara H, Sugioka H, Ito A, Isse T, Kasaya T, Tada N, Baba K, Abe N, Hamano Y, Tarits P, Barriot JP, Reymond D (2012) TIARES projecttomographic investigation by seafloor array experiment for the Society hotspot. Earth Planets Space 64(4):i-iv

Takeuchi H, Saito M (1972) Seismic surface waves. In: Bolt BA (ed) Seismology: surface waves and free oscillations, methods in computational physics, vol 11. Academic Press, New York, pp 217-295

Tarantola A, Valette B (1982) Generalized nonlinear inverse problems solved using the least-squares criterion. Rev Geophys 20:219-232

Wessel P, Smith WHF (1991) Free software helps map and display data. EOS Trans AGU 72(41):441, 445-446 